\title{
New records and range extension of Habenaria dutrae Schltr. (Orchidaceae) in southern Rio Grande do Sul, Brazil
}

\author{
Gustavo Crizel Gomes ${ }^{1}$, Artur Ramos Molina ${ }^{2}$, Ernestino S. G. Guarino ${ }^{3}$, Thales Castilhos de \\ Freitas $^{2}$, Tângela Denise Perleberg ${ }^{4}$
}

\begin{abstract}
1 Universidade Federal de Pelotas, Programa de Pós-Graduação em Desenvolvimento Territorial e Sistemas Agroindustriais, Av. Eliseu Maciel (sn), Campus Capão do Leão, CEP: 96010-900, Capão do Leão, RS, Brazil. 2 Universidade Federal de Pelotas, Instituto de Biologia, Campus Capão do Leão, CEP: 96010-900, Capão do Leão, RS, Brazil. 3 Embrapa Clima Temperado, BR 392, km 78, $9^{\circ}$ Distrito, Monte Bonito, CEP: 96010-971, Pelotas, RS, Brazil. 4 Instituto Federal de Educação, Ciência e Tecnologia Sul Rio Grandense, Campus Pelotas Visconde da Graça, AV. Engenheiro Ildefonso Simões Lopes, 2791, CEP 96060-290, Pelotas, RS, Brazil.

Corresponding author: Gustavo Crizel Gomes, crizelgomes@gmail.com
\end{abstract}

\begin{abstract}
We describe 4 new records of Habenaria dutrae Schltr., a threatened orchid species that is endemic of Rio Grande do Sul state, Brazil. The new record, from Pontal da Barra, increases the distribution of H. dutrae by approximately 180 $\mathrm{km}$ south and represents the southernmost known location for the species. We also re-evaluate the conservation status of the species including the new records, finding it to be Endangered under criteria B2ab(iii); D.
\end{abstract}

\section{Key words}

Orchidoideae; wetlands; swamp forests; Pampa biome; endemism.

\section{Introduction}

The family Orchidaceae, the most diverse family among the angiosperms, comprises 899 genera and approximately 27,801 species (The Plant List 2015, Givnish et al. 2016). Its distribution is cosmopolitan, except for dry deserts and the Antarctic continent (Hágsater and Dumont 1996). In Brazil, it is represented by approximately 221 genera and 2,472 species (Flora do Brasil 2018).

The genus Habenaria Willd. has approximately 870 species, and within subfamily Orchidoideae, it has the highest number of species (Govaerts et al. 2017) and is the largest genus of terrestrial orchids in the world (Batista et al. 2011). With approximately 153 species in Brazil Habenaria is the genus of Orchidaceae with high- est species richness in the county (Flora do Brasil 2018). In Rio Grande do Sul state there are 33 species recorded (Batista et al. 2012).

Habenaria dutrae Schltr. is considered rare and endemic to Rio Grande do Sul (Batista et al. 2012). Its occurrence is predominantly associated with swamp forests (Rocha and Waechter 2006) and wetlands of the coastal plain (Pedron et al. 2014). This species is considered Critically Endangered (criteria B1ab(iii) + 2ab(iii); D) in Rio Grande do Sul (FZB 2014), but it is not included in the Red Book of the Flora of Brazil (Martinelli and Moraes 2013). Habenaria dutrae was previously evaluated according to the categories and criteria of the Red List of the International Union for Conservation of 
Table 1. Data from previous collection of Habenaria dutrae. Legend: * Habenaria schnittmeyeri Schltr. (Synonym); ** Possibly flowers of the isotypus (J. Dutra 995).

\begin{tabular}{llll}
\hline Collector/voucher & Locality & Date of collection & Identifier \\
\hline J. Dutra 675 (ICN) & São Leopoldo, Fazenda dos Prazeres & 1904 & F. R. F. Schlechter \\
J. Dutra 995* (ICN) & São Leopoldo & ix.1925 & F. C. Hoehne; J. Dutra \\
Schiedmeyer w.n.** (SP) & São Leopoldo & 1925 & J. A. N. Batista \\
P. C. Orth 579 (PACA) & Porto Alegre & 1933 & J. Dutra \\
C. O. Lindholm w.n. (PACA) & Porto Alegre, Vila Manresa & $12 . i .1933$ & J. Dutra conf. G. F. J. Pabst \\
L. Ortl \& J. Dutra w.n. (SP) & Porto Alegre, Maria da Glória & $20 . i .1933$ & Unavailable \\
B. Rambo w.n. (PACA) & Osório, Fazenda do Arroio & $04 . i .1950$ & J. A. N. Batista \\
P. C. Orth 1147 (HB) & Porto Alegre & $12 . i i .1960$ & Unavailable \\
M. Pedron 3 (ICN) & Santo Antônio da Patrulha & $20 . i .2011$ & M. Pedron \\
C. R. Buzatto 774 \& M. H. Nervo (ICN) & Vacaria & $21 . i i .2012$ & Unavailable \\
\hline
\end{tabular}

Nature by Pedron et al. (2014) as Endangered (criteria B1ab(iii) + 2ab(iii); D). This species was recorded in only 5 municipalities, as shown in Table 1.

In this study, we expand the geographic distribution of $H$. dutrae and characterize the environments where the species occurs. We also re-evaluate the conservation status of the species based on the IUCN categories and criteria and including the new records.

\section{Methods}

The first author coincidentally found a population of H. dutrae in Altos do Laranjal, Pelotas, Rio Grande do Sul. In the following months, between January and
May of 2018, we undertook field trips in search of other populations in Altos do Laranjal and other humid areas in Rio Grande do Sul. The geographic coordinates were obtained in the field using Garmin GPSMAP ${ }^{\circledR} 64$. To create the geographic distribution map (Fig. 1) we used the points of observation of $H$. dutrae from our field trips and information available in SpeciesLink (http://splink.cria. org.br/), Reflora (http://reflora.jbrj.gov.br), and Global Biodiversity Information Facility (http://www.gbif.org/). We used a portable photo studio to get detailed pictures of the inflorescence and flowers. Botanical collections were not undertaken due to delay in emission of specific licenses by the environmental agencies in Brazil (Sistema de Autorização e Informação em Biodiversidade; http://

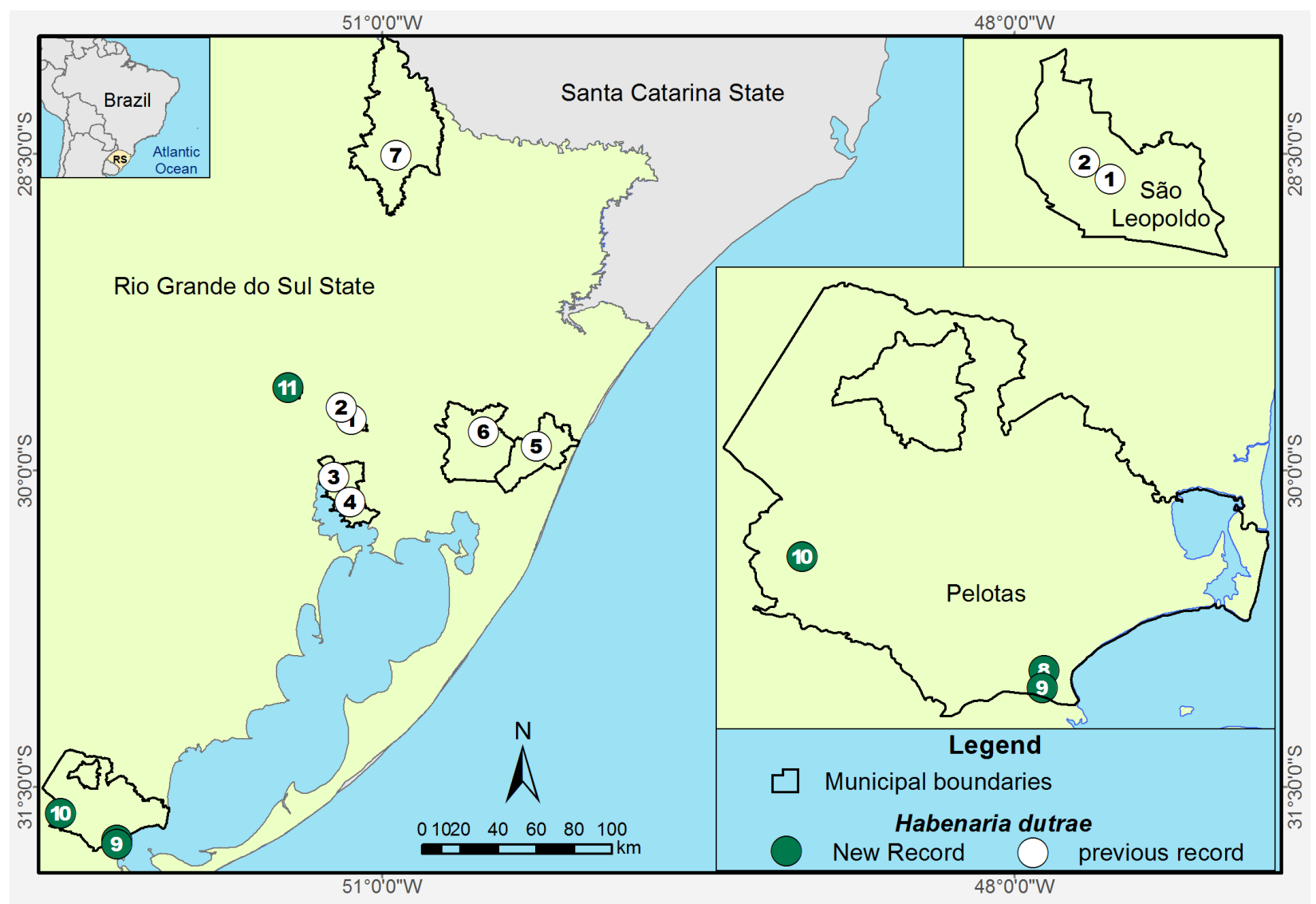

Figure 1. Habenaria dutrae new records of occurrence (green) and previous records (white): 1. São Leopoldo; 2. São Leopoldo; 3. Glória, Porto Alegre; 4. Vila Manresa, Porto Alegre; 5. Osório; 6. Santo Antônio da Patrulha; 7. Vacaria; 8. Altos do Laranjal, Pelotas; 9. Pontal da Barra, Pelotas; 10. Cascata, Pelotas; 11. Coqueiral, Pareci Novo. 
www.icmbio.gov.br/sisbio/). As a geophyte species, the aerial part dehydrates from apex to base, starting in April and becomes unavailable to collect after that. For re-evaluation of the conservation status of $H$. dutrae we used the IUCN Red List categories and criteria (IUCN 2012). We calculated the Extent of Occurrence (EOO) and Area of Occupancy (AOO; grid size $=4 \mathrm{~km}^{2}$ ). Spatial analysis (EOO and AOO) and the distribution map (Fig.1) were done using the software QuantumGIS v. 3.2.3 (QGIS Development Team 2018).

The species was identified based on Pedron et al. (2014). Two specialists evaluated the photographic material and confirmed the identification (M. Pedron pers. comm.; J.A.N. Batista pers. comm.). We also examined dried specimens in the Herbarium ICN and digital images available in the same data bases used to create the distribution map.

\section{Results}

Habenaria dutrae Schltr., Repert. Spec. Nov. Regni Veg. Beih. 35: 19 (1925).

Type. Brazil. Rio Grande do Sul: São Leopoldo, Fazenda dos Prazeres, Feb. 1904, J. Dutra 675 (ICN014675!).

New records (Fig. 1). Brazil: Rio Grande do Sul: Pelotas: Altos do Laranjal ( $31^{\circ} 45^{\prime} 04^{\prime \prime} \mathrm{S}, 052^{\circ} 15^{\prime} 28^{\prime \prime} \mathrm{W}$; WGS84), observed by Gustavo Gomes, Artur Molina, Ernestino Guarino and Thales Freitas, 12 Jan. 2018 (population size ca 30 individuals). Brazil: Rio Grande do Sul: Pelotas: Pontal da Barra $\left(31^{\circ} 46^{\prime} 12^{\prime \prime} \mathrm{S}, 052^{\circ} 15^{\prime} 18^{\prime \prime} \mathrm{W}\right)$, observed by Gustavo Gomes and Fernando Jacobs, 1 Feb. 2018 (4 individuals). Brazil: Rio Grande do Sul: Pelotas: Cascata (313'ㄱ' ${ }^{\prime \prime}$ S, 052 31'42" W), observed by Artur Molina, Thales Freitas and Vinicius Espindola, 7 Feb. 2018 (ca 50 individuals). Brazil: Rio Grande do Sul: Pareci Novo: Coqueiral $\left(29^{\circ} 36^{\prime} 28^{\prime \prime} \mathrm{S}, 051^{\circ} 26^{\prime} 56^{\prime \prime} \mathrm{W}\right)$, observed by Daniel Derlam, Feb. 2018 (14 individuals).

Additional specimens examined. Porto Alegre, Morro da Glória, Vila Manresa, 20 Jan. 1933, Orth 579 (K000396197 [image!], S10-20647 [image!]); Santo Antônio da Patrulha, 20 Jan. 2011, M. Pedron, 3 (ICN 169158!).

Identification. Semi-aquatic, geophyte, erect herb. 50 $150 \mathrm{~cm}$ high (inflorescence included). Angular green stem $3-7 \mathrm{~mm}$ in diameter. Leaves 8 to $18,5-21 \times 3-6.5$ $\mathrm{cm}$, ovate-lanceolate, amplexicaul, parallel-veined, 3 deeply canaliculate veins. Inflorescence 10-28 cm, many flowered, congested. Bracts ovate-lanceolate, acuminate, generally shorter than the pedicellate ovary. Flowers 20 60 , pedicellate ovary parallel to the rachis or spreading from it. Petals, sepals and labellum light green. Ovary arched 13-15 mm, pedicel 2.5-4.0 mm. Sepals green, mucronate, margins smooth; dorsal sepal slightly concave, when flattened orbicular. Petals bipartite, base whitish, turning greenish yellow towards the apex. Capsules $10-15 \times 2-4 \mathrm{~mm}$, peduncle protected by a bract. Fruit

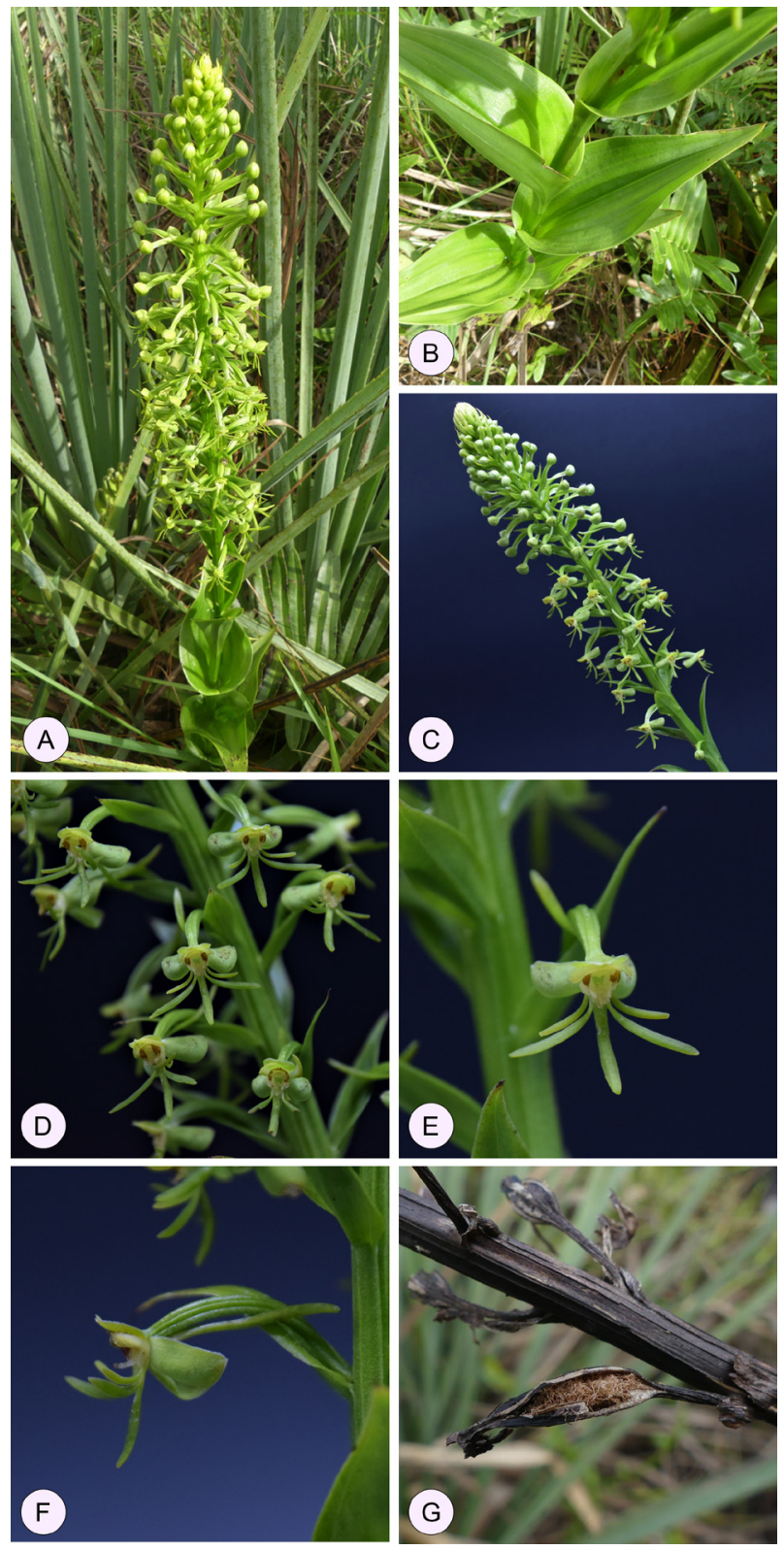

Figure 2. Habenaria dutrae: A. General appearance. B. Leaves. C. Inflorescence. D. Inflorescence detail. E. Frontal view of the flower. F. Lateral view of the flower. G. Mature fruits. Locality for A, B: Altos do Laranjal; C-G, Cascata.

dehiscence starts when the plant is completely dry (Fig. $2 \mathrm{~A}-\mathrm{G})$.

According to Pedron et al. (2014), H. dutrae differs from $H$. ekmaniana Kraenzl., the most morphologically similar species, because:

In $H$. dutrae the lateral lobes of the lip are linear and longer than the median lobe, and the anterior lobe of the petals is longer than the posterior one, whereas, in $H$. ekmaniana, both petal and labellum lobes are similarly sized and the lip lobes are oblanceolate in shape.

However, their key, Rocha and Waechter (2006) considered that the middle segment of the labellum has approximately the same length as the side ones.

Distribution and conservation. This species is presently considered rare by Rocha and Waechter (2006). Natural 

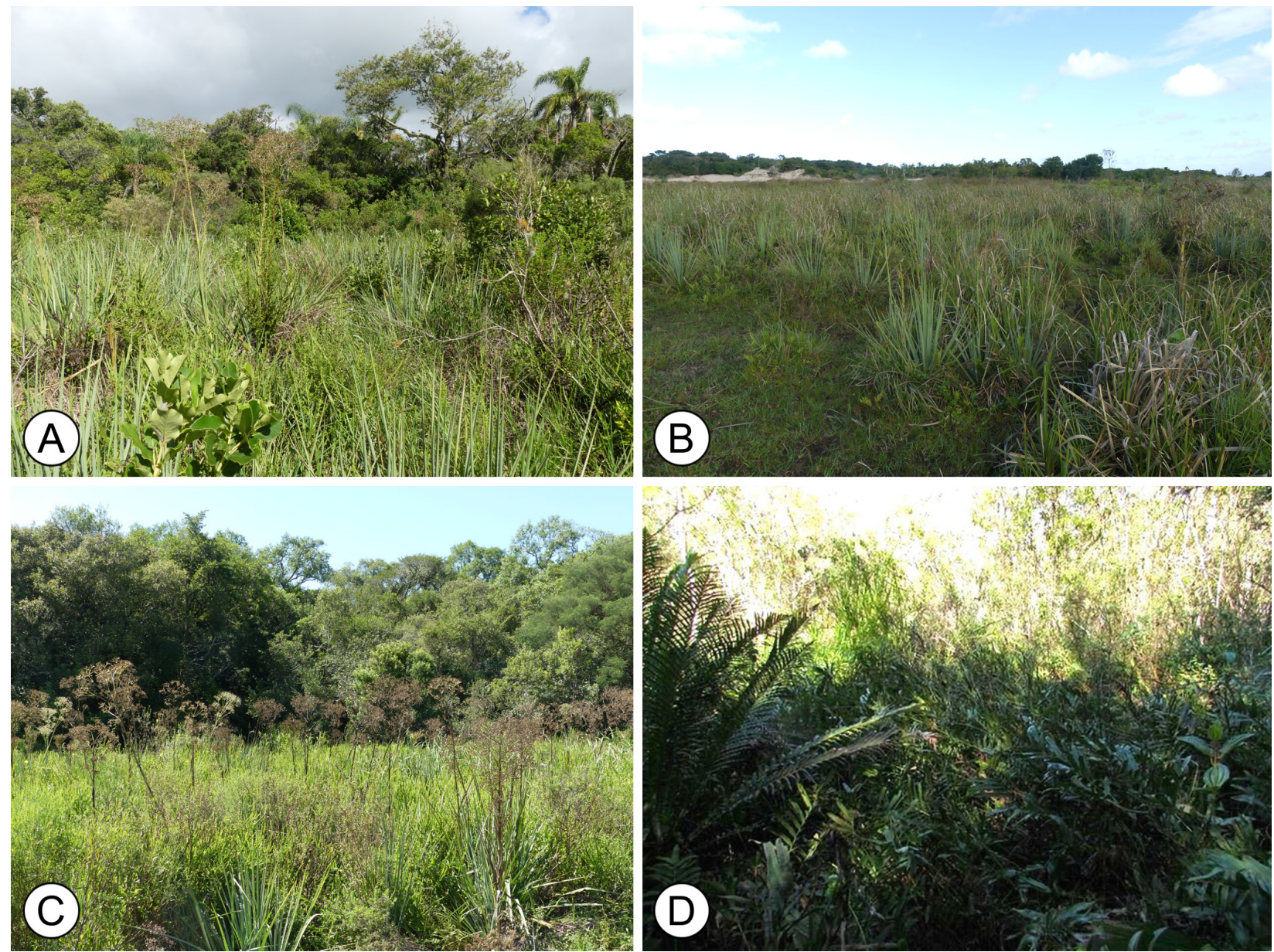

Figure 3. Vegetation types of the new records. A. Transition between coastal wetlands and swamp forests; Altos do Laranjal. B. Swamp vegetation interspersed with dunes and sandy forests; Pontal da Barra. C. Wetlands among seasonal forests; Cascata. D. Wetlands among seasonal forests; Coqueiral.

populations were found in humid areas in the coastal plains of eastern Rio Grande do Sul, in the border of swamp and sandy forests (elevation 5-10 m above sea level); in highlands humid areas in Vacaria municipality (highland grasslands, ca $500 \mathrm{~m}$ above sea level; C. Buzatto and M. Nervo, cited by Pedron et al. 2014); in the hillside of the Serra do Sudeste range (160 m above sea level), in the border of the Seasonal Forest in Pelotas municipality, and in the humid areas of the Central Depression, in Pareci Novo municipality.

The locality of Altos do Laranjal (Fig. 3A) is characterized by a transition between coastal wetlands and swamp forests (locally known as "Mata de restinga paludosa"). The population of Pontal da Barra locality (Fig. 3B) occurs in the lower areas, in a swamp vegetation dominated by Androtrichum trigynum (Spreng.) H. Pfeiff. interspersed with dunes and sandy forests (locally know as "Mata de restinga arenosa"). In these two localities the species was associated with populations of Eryngium pandanifolium Cham. \& Schltdl. These types of vegetation are increasingly rare in the coastal plains of southern Rio Grande do Sul, due to agriculture and real estate speculation (Burger and Ramos 2006). The Cascata population (Fig. 3C) was also associated with E. pandanifolium, and at Coqueiral (Fig. 3D) the species was found among veg- etation composed by Cyperus sp. Both populations were found in wetlands among seasonal forests.

The EOO of the species, based on the new records, is $26,852 \mathrm{~km}^{2}$ and the AOO is $36 \mathrm{~km}^{2}$. The species AOO is less than $500 \mathrm{~km}^{2}$, and populations described before 1960 occur in heavily modified areas. Current records are composed of less than 250 mature individuals. Although the orchids show a great production of seeds of anemocoric dispersion, the most seeds fall and develop in the proximity of the maternal plant (Chung et al. 2005), presenting significant genetic clustering on a scale of approximately $5 \mathrm{~m}$ (Chung et al. 2004). Considering the low mobility of this species, the small and relatively isolated subpopulations, subjected to strong anthropogenic pressure, we consider populations "severely fragmented" as more than half of the individuals are under these conditions (IUCN Standards and Petitions Subcommittee 2017). Therefore the category remains the same as that proposed by Pedron et al. (2014), even though there were changes in the evaluation criteria: Endangered under criteria B2ab(iii); D.

\section{Discussion}

The occurrence of Habenaria dutrae was originally thought to relate to vegetation of humid environments 
in Rio Grande do Sul coastal plains (Rocha and Waechter 2006) and specifically to areas of the metropolitan region of Porto Alegre and the northern coast of Rio Grande do Sul. The records from Pontal da Barra (Pelotas) extend the geographic distribution of $H$. dutrae by approximately $180 \mathrm{~km}$ south of the southernmost known location (Porto Alegre municipality). This occurrence and the record in Vacaria municipality (C. Buzatto and M. Nervo, cited by Pedron et al. 2014) demonstrate that $H$. dutrae is not restricted to the metropolitan region of Porto Alegre and the northern coast of Rio Grande do Sul, as previously suggested. Some of the newly reported populations of $H$. dutrae are from humid areas at the edge of Semideciduous Seasonal Forest fragments on the hillsides of the Serra do Sudeste at Cascata (Pelotas municipality) and in the Central Depression, at Coqueiral (Pareci Novo municipality).

The geophyte habit of $H$. dutrae, its adaptation to humid areas, and its association with other species that together form dense populations make it difficult to find. The scarcity of records might be associated more with a scarcity of sampling than with rarity of the species. Recently, Singer et al. (2018) rediscovered Codonorchis canisioi (Brogn.) Lindl., another rare and endemic orchid species from Rio Grande do Sul and mentioned that habitat characteristics, morphological aspects of plants, and anthropic activities can make it more difficult to locate rare species. This corroborates our observations for $H$. dutrae.

Our data considerably increases the number of records and area of occurrence, which are useful for updating this species' conservation status. The description of habitats and the occurrence map may be useful to modeling the distribution of $H$. dutrae with the goal to locate additional populations.

\section{Acknowledgements}

We thank Marcelo Pedron and João Aguiar Nogueira Batista for their help to confirm the identification, Henrique Cunha for creating the location image, Omar Machado Entialspe-Neto and Marcelo Piske Eslabão for their suggestions on the manuscript, Daniel Derlam for data on the occurrence of $H$. dutrae in Pareci Novo, and Paulo Ricardo Faraco for his company in the field.

\section{Authors' Contributions}

GCG, ARM, ESGG, TCF collected data in the field; GCG, ARM, TCF identified the taxa; GCG, ARM , ESGG, TCF, and TDP wrote the manuscript.

\section{References}

Batista JAN, Bianchetti LB, González-Tamayo R, Figueroa XMC, Cribb PJ (2011) A synopsis of new world Habenaria (Orchidaceae) I. Harvard Papers in Botany 16 (1): 1-47.
Batista JAN, Neto LM, Vale AA (2012) Three new species, four new records and an updated checklist of Habenaria (Orchidaceae) from Rio Grande do Sul, Brazil. Nordic Journal of Botany 30 (3): 277-290. https://doi.org/10.1111/j.1756-1051.2012.01349.x_

Burger MI, Ramos RA (2006) Áreas importantes para a conservação da Planície Costeira do Rio Grande do Sul. In: Becker FG, Ramos RA, Moura LA. (Eds) Biodiversidade. Regiões da Lagoa do Casamento e dos Butiazais de Tapes, planície costeira do Rio Grande do Sul. Ministério do Meio Ambiente, Brasília, 46-58.

Chung MY, Nason JD, Chung MG (2004) Implication of clonal structure for effective population size and genetic drift in a rare terrestrial orchid, Cremastra appendiculata. Conservation Biology 18 (6): 1515-1524. https://doi.org/10.1111/j.1523-1739.2004.00291.x

Chung MY, Nason JD, Chung MG (2005) Spatial genetic structure in populations of the terrestrial orchid Orchis cyclochila (Orchidaceae). Plant Systematics and Evolution 254 (3-4): 209-219. https:// doi.org/10.1007/s00606-005-0341-5

Flora do Brasil (2018) Flora do Brasil 2020 [under construction]. Rio de Janeiro Botanical Garden. http://floradobrasil.jbrj.gov.br/reflora/ floradobrasil/FB179. Accessed on: 2018-10-10.

FZB (2014) Lista vermelha das espécies da flora ameaçadas de extinção no Rio Grande do Sul. http://www.fzb.rs.gov.br/conteudo/2403/ ?Informações_da_Biodiversidade. Accessed on: 2017-06-13.

Givnish TJ, Spalink D, Ames M, Lyon SP, Hunter SJ, Zuluaga A, Doucette A, Caro GG, McDaniel J, Clements MA, Arroyo MTK, Endara L, Kriebel R, Williams NH, Cameron KM (2016) Orchid historical biogeography, diversification, Antarctica and the paradox of orchid dispersal. Journal of Biogeography, 43 (10): 1905-1916. https://doi.org/10.1111/jbi.12854

Govaerts R, Bernet P, Kratochvil K, Gerlach G, Carr G, Alrich P, Pridgeon AM, Pfahl J, Campacci MA, Holland Baptista D, Tigges H, Shaw J, Cribb PJ, George A, Kreuz K, Wood JJ (2017) World checklist of Orchidaceae. The Royal Botanic Gardens, Kew. http:// apps.kew.org/wcsp. Accessed on: 2017-07-22.

Hágsater E, Dumont V (1996) Orchids. Status Survey and Conservation Action Plan. IUCN, Gland-Switzerland, $153 \mathrm{pp}$.

IUCN (2012) IUCN Red List Categories and Criteria: version 3.1. Second edition. IUCN, Gland, Switzerland and Cambridge, 32 pp. http://s3.amazonaws.com/iucnredlist-newcms/staging/public/attach ments/3097/redlist_cats_crit_en.pdf. Accessed on: 2018-10-14.

IUCN Species Survival Commission (2017) Guidelines for Using the IUCN Red List Categories and Criteria: Version 13. IUCN Standards and Petitions Subcommittee, 108 pp. http://www.iucnredlist. org/documents/RedListGuidelines.pdf. Accessed on: 2018-11-04.

Martinelli G, Moraes MA (2013) Livro Vermelho da Flora do Brasil. Jardim Botânico do Rio de Janeiro, Rio de Janeiro, 1100 pp.

Pedron M, Buzatto CR, Ramalho AJ, Carvalho BM, Radins JA, Singer RB, Batista JAN (2014) Molecular phylogenetics and taxonomic revision of Habenaria section Pentadactylae (Orchidaceae, Orchidinae). Botanical journal of the Linnean Society 175 (1): 47-73. https://doi.org/10.1111/boj.12161

QGIS Development Team (2018). QGIS, version 3.2.3. Open Source Geospatial Foundation Project.

Rocha FS, Waechter JL (2006) Sinopse das Orchidaceae terrestres ocorrentes no litoral norte do Rio Grande do Sul, Brasil. Acta Botanica Brasilica, 20 (1): 71-86. https://doi.org/10.1590/S010233062006000100008

Schlechter R (1925) Die Orchideenflora von Rio Grande do Sul. II. Besprechung der Gattungen und Arten. I. Habenaria. Repertorium Specierum Novarum Regni Vegetabilis 35: 17-23.

Singer RB, Buzatto CR, Sanguinetti A, Nervo MH (2018) Found again: the extremely rare Codonorchis canisioi (Orchidaceae: Codonorchideae) reappears after being missing for 78 years. Plant Systematics and Evolution 304 (9): 1157-1663. https://doi.org/10.1007/ s00606-018-1538-8

The Plant List (2015) https://www.theplantlist.org. Accessed on: 201707-20. 